\title{
Unexpected result for the acylation of arylhydrazonoethanethioamides
}

\author{
Anastasiya I. Bolgova ${ }^{a}$, Kseniya I. Lugovik ${ }^{\text {a }}$, Julia O. Subbotina ${ }^{\text {a,b }}$, Pavel A. Slepukhin ${ }^{\text {b }}$, \\ Vasiliy A. Bakuleva ${ }^{a}$ Nataliya P. Belskaya ${ }^{a, *}$ \\ ${ }^{a}$ Urals Federal University, Mira Str. 19, Ekaterinburg 620002, Russia \\ ${ }^{\mathrm{b}}$ I. Ya. Postovsky Institute of Organic Synthesis of the Ural Branch of Russian Academy of Sciences, S. Kovalevskaya Str. 20, Ekaterinburg 620219, Russia
}

\section{A R T I C L E I N F O}

\section{Article history:}

Received 21 December 2012

Received in revised form 30 May 2013

Accepted 17 June 2013

Available online 26 June 2013

\section{Keywords:}

Arylhydrazonoethanethioamide

Acylation

1,2,3-Thiadiazole

Oxidation

Thiapentalene

\begin{abstract}
A B S T R A C T
The acylation of arylhydrazonoethanethioamides containing primary amino group did not yield acylthioamides as expected. Surprisingly, the cyclic 5-acylimino-2,5-dihydro-1,2,3-thiadiazoles were obtained. The formation of thiadiazoles in this reaction was explained by the higher ability of arylhydrazono- $N$-acylthioacetamide intermediates to be oxidized comparing to their precursors. The presence of pseudobicyclic aromatic structure in the reaction product was a main factor favoring the formation of 1,2,3-thiadiazole ring.
\end{abstract}

(C) 2013 Elsevier Ltd. All rights reserved.

\section{Introduction}

Arylhydrazonoethanethioamides are often used as precursors to various heterocyclic compounds. ${ }^{1}$ Their $\pi$-system is highly conjugated and enriched by lone pairs of electrons and/or mobile protons. As a result, very simple modifications, such as acylation or alkylation, quite often lead to unusual cascade-like transformations and unexpected products. ${ }^{1 \mathrm{~b}, \mathrm{c}}$

We focused our study on acylation of arylhydrazonoethanethioamides $\mathbf{1}$, functionalized with a primary amine group, assuming that the presence of several nucleophilic centers in thioamides $\mathbf{1}$ might lead to the formation of linear and cyclic products. Either $\mathrm{N}$-acylhydrazones $\mathbf{4}$ or $\mathrm{N}$-acylthioamides $\mathbf{5}$, and products of their intramolecular cyclization, 1,2,4-triazinthiones 6 (Scheme 1) were expected. This is a new approach to the synthesis of 5-thioxo-2,5dihydro-1,2,4-triazines $\mathbf{6}$ and hasn't been reported previously. Further modifications of active functional groups in compounds $\mathbf{6}$ could also open a new route for the synthesis of bioactive 1,2,4triazines. ${ }^{2}$ The convenience of compounds $\mathbf{1}$ as models to study the reactivity of functionalized arylhydrazones with multiple nucleophilic centers is also important. ${ }^{1 \mathrm{a}}$

\footnotetext{
* Corresponding author. E-mail address: n.p.belskaya@ustu.ru (N.P. Belskaya).
}

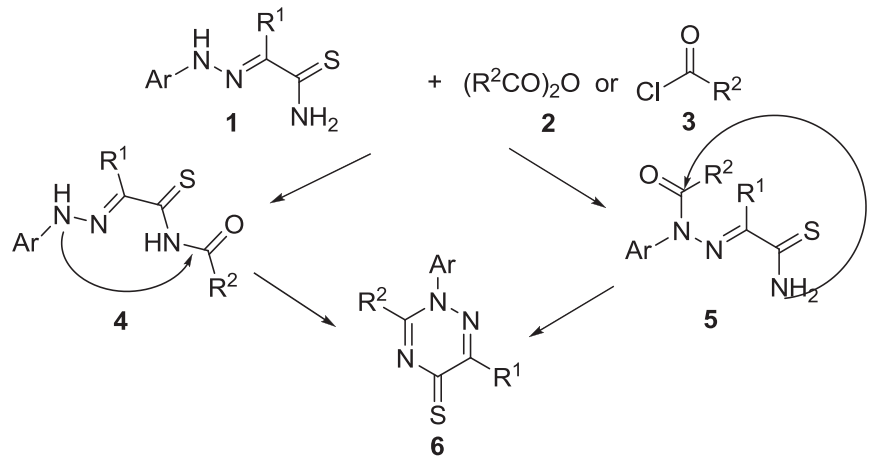

Scheme 1. Expected directions of the acylation of hydrazonoethanthioamides $\mathbf{1}$.

\section{Results and discussion}

The acylation of hydrazonoethanethioamides 1a-e with anhydride $\mathbf{2}$ or acyl chloride $\mathbf{3}$ was performed in pyridine (Scheme 2). Surprisingly for us the 5-acylimino-2,5-dihydro-1,2,3-thiadiazoles $\mathbf{7 a}-\mathbf{j}$ were formed instead of desired compounds $\mathbf{4 - 6}$.

Elemental analysis and all spectral data supported the formation of products $\mathbf{7 a}-\mathbf{j}$. Mass-spectrometry data exhibited a molecular ion peak of 5-acylimino-2,5-dihydro-1,2,3-thiadiazoles, which differed by two units from the molecular ion peak of assumed 


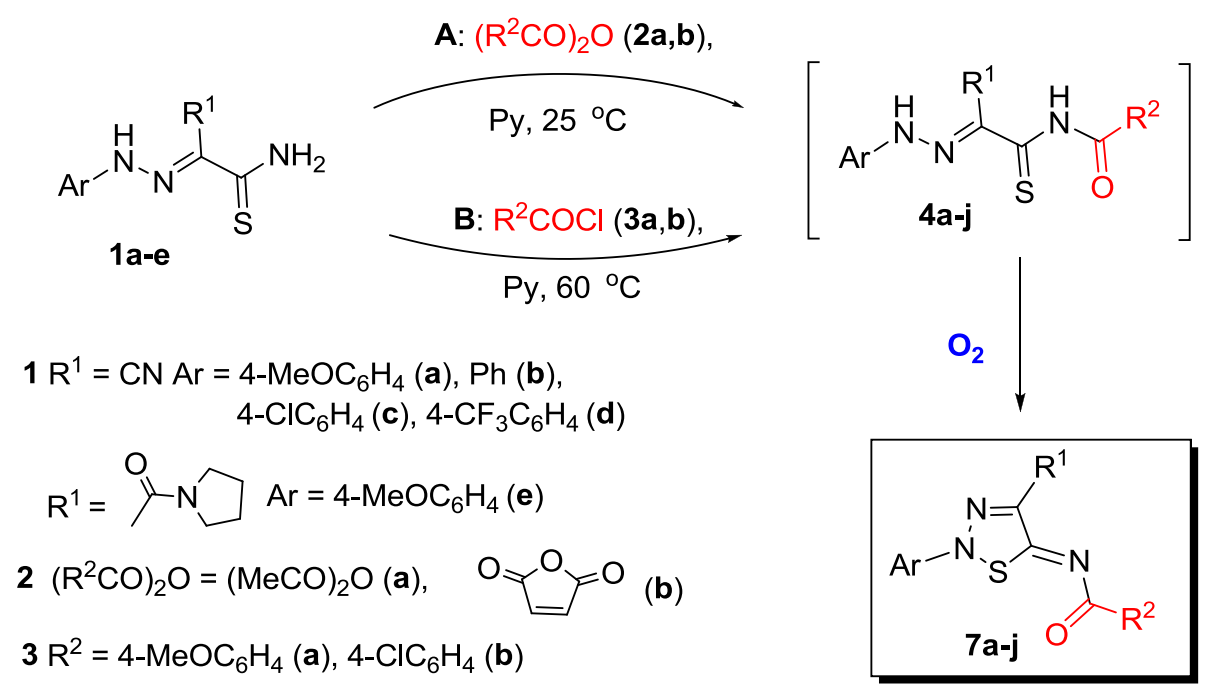

Scheme 2. Synthesis of (2-aryl-1,2,3-thiadiazol-5(2H)-ylidene)acetamides 7.

structure for acyl derivatives $\mathbf{4}$ or $\mathbf{5} .{ }^{1} \mathrm{H}$ NMR spectra of compounds $\mathbf{7 a}-\mathbf{j}$ displayed signals for proton-bearing groups for acyl moiety $\left(\mathrm{R}^{2}\right)$. Furthermore, there were no signals corresponding to the protons of NH-groups in ${ }^{1} \mathrm{H}$ NMR spectra.

Also, several unusual data were found in spectra for compounds 7. For example, absorption band of $\mathrm{C} \equiv \mathrm{N}$ bond for the thiadiazoles $\mathbf{7 a}-\mathbf{f}$ in IR spectra shifted to the region with higher frequency $\left(2234-2241 \mathrm{~cm}^{-1}\right)$. The signal for $\mathrm{C}=\mathrm{O}$ bond of acyl group moved to lower frequency $\left(1583-1610 \mathrm{~cm}^{-1}\right)$. The singlet of carbon atom of carbonyl group in ${ }^{13} \mathrm{CNMR}$ spectra was registered in downfield region.

There was only one set of signals in ${ }^{1} \mathrm{H}$ and ${ }^{13} \mathrm{C}$ spectra. Whereas compounds with double exocyclic $\mathrm{C}=\mathrm{N}$ bond usually exist in the form of two stereoisomers (Scheme 3) with two sets of signals appearing in NMR spectra. For example, the formation of two stereoisomers for alkyl derivatives of 5-imino-1,2,3-thiadiazole was registered by two sets of signals in ${ }^{1} \mathrm{H}$ and ${ }^{13} \mathrm{C}$ NMR experements. ${ }^{3}$

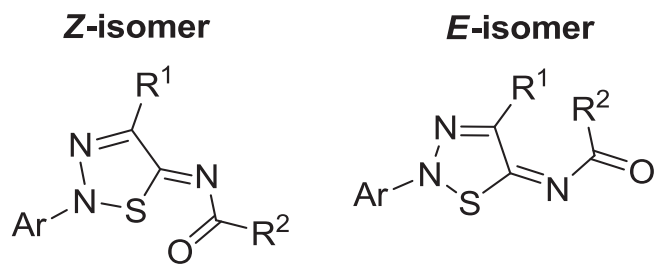

Scheme 3. Proposed isomers for (2-aryl-1,2,3-thiadiazol-5(2H)-ylidene)acetamides 7.

The mechanism for the formation of 5-acylimino-2,5-dihydro1,2,3-thiadiazoles $\mathbf{7 a}-\mathbf{j}$ is an oxidative cyclization of interim 4 following the initial acylation (Scheme 2).

It should be mentioned that oxidation is one of the most typical transformations in the chemistry of thioamides, ${ }^{1 \mathrm{a}, 3,4}$ although, it does not occur simultaneously without an added oxidant. Oxidation of arylhydrazonoethanethioamides takes place only in the presence of bromine, iodine or $\mathrm{N}$-chlorosuccinimide and yields 5 -iminothiadiazoles. ${ }^{3,4}$ Last ones are unstable and exists exclusively in salt forms (chlorides, bromides, and iodides). They undergo diverse transformations under the heating in pyridine. As a result, acylation of 5-iminothiadiazoles involves their reflux in pyridine with acyl chloride and frequently is accompanied by the formation of the byproduct. ${ }^{5}$

5-Acylimino-1,2,3-thiadiazoles 7a-j listed in Table 1 have never been described before to our best knowledge. To prove their structure, retrospective synthesis was performed as shown on Scheme 4. Compounds 7a,g were synthesized via acylation of 2-aryl-2,5-dihydro-1,2,3-thiadiazoliminium bromides $\mathbf{8 a , b}$ as it was published earlier. ${ }^{5}$

${ }^{13} \mathrm{C}$ and ${ }^{1} \mathrm{H}$ NMR spectra, mass spectra, and melting points for (1,2,3-thiadiazol-5(2H)-ylidene)acetamides $\mathbf{7 a , g}$ synthesized by two different methods were identical (Scheme 4).

X-ray diffraction data for compounds $\mathbf{7 d , g , h}$ were in line with other spectral data described above and established that the molecules exist in their $Z$-isomeric form constrained by an $\mathrm{S} \cdots \mathrm{O}$ bond. The distance between the carbonyl oxygen and thiadiazole sulfur atoms was substantially shorter than the sum of Van der Waals radii for those atoms (Figs. 1-3 and Fig. S1-S3 in Supplementary data). The bonds in the thiadiazole ring $(\mathrm{N}(2)=\mathrm{N}(3), \mathrm{N}(3)-\mathrm{C}(4), \mathrm{C}(4)-\mathrm{C}(5)$, $\mathrm{C}(5)-\mathrm{S}(1), \mathrm{S}(1)-\mathrm{N}(2))$, and iminoacyl fragment $(\mathrm{C}(5)-\mathrm{N}(6), \mathrm{N}(6)-$ $\mathrm{C}(7), \mathrm{C}(7)=\mathrm{O}(8)$ ) were substantially distorted for $\mathbf{7 d , g , h}$ compared to standard bond lengths (Fig. S1-S3). ${ }^{6}$ The $\pi$-conjugated heteroatomic system was planar. The maximal deviation of terminal atoms in side chains from the least-squared plane was less than $0.07 \AA$. The bond angles $\mathrm{N}(2)-\mathrm{S}(1)-\mathrm{O}(8)$ in structures $7 \mathbf{d}, \mathbf{g}, \mathbf{h}$ were approximately linear (Figs. 1-3). It has been shown previously that such an arrangement of atoms governs an overlapping of non-bonding $n(\mathrm{O})$ orbital located on oxygen and vacant $\sigma^{*}(\mathrm{~S}-\mathrm{N})$ orbital located on $\mathrm{S}-\mathrm{N}$ bond. Intramolecular non-covalent $S \cdots O$ bond was formed in compounds 7d,g,h and resulted in their extra stabilization (Fig. 4).

The nature of the non-covalent $\mathrm{S} \cdots \mathrm{X}(\mathrm{X}=\mathrm{S}, \mathrm{N}, \mathrm{O})$ interaction between the two electron-rich centers within one molecule has attracted special attention from experimentalists and theoreticians from different fields. ${ }^{7,8}$ It was shown that in some cases that the S...O interaction determined backgrounds of several biological phenomena or was responsible for enhanced druggability of compounds. For example, the increase of antitumor activity of angiotensin II receptor $\left(\mathrm{AT}_{1}\right)$ antagonists was linked to the presence of S...O non-covalent bond. ${ }^{8 \mathrm{C}}$ Thus, designing new molecular structures with $\mathrm{S} \cdots \mathrm{O}$ contact seems to be an efficient approach toward the development of various drugs.

Furthermore, the introduction of an S ...O interaction increased the conformational rigidity of oligothiophenes and enhanced their photophysical and conductive properties. ${ }^{9}$ Thus, molecules constrained by strong $\mathrm{S} \cdots \mathrm{O}$ bond can be used as building blocks to construct supramolecular structures being of interest to material science. $^{7 \mathrm{c}, 9}$

The strength and nature of $n(\mathrm{O}) \rightarrow\left[\sigma^{*}(\mathrm{~S}-\mathrm{N})\right]$ interaction can be studied with the help of computational chemistry methods (NBO, AIM etc.). ${ }^{8 a, c, 10}$ The simplest (but rough) criteria to evaluate benefits of stabilization due to intramolecular S ...O interaction would be 
Table 1

(2-Aryl-1,2,3-thiadiazol-5(2H)-ylidene)acetamides 7a-j produced via Scheme 2 (conditions A and B)

\begin{tabular}{|c|c|c|c|c|c|c|c|c|}
\hline Entry & Compound & $\mathrm{Ar}$ & $\mathrm{R}^{1}$ & $\mathrm{R}^{2}$ & $T\left({ }^{\circ} \mathrm{C}\right)$ & Method & Time (h) & Yield ${ }^{\mathrm{a}}(\%)$ \\
\hline 1 & $7 a$ & $4-\mathrm{MeOC}_{6} \mathrm{H}_{4}$ & $\mathrm{CN}$ & $\mathrm{Me}$ & 25 & $\mathrm{~A}$ & 6 & 62 \\
\hline 2 & $\mathbf{7 b}$ & $\mathrm{Ph}$ & $\mathrm{CN}$ & Me & 25 & A & 11 & 54 \\
\hline 3 & 7c & $4-\mathrm{ClC}_{6} \mathrm{H}_{4}$ & $\mathrm{CN}$ & Me & 25 & A & 48 & 69 \\
\hline 4 & 7d & $4-\mathrm{CF}_{3} \mathrm{C}_{6} \mathrm{H}_{4}$ & $\mathrm{CN}$ & $\mathrm{Me}$ & 25 & A & 10 & 62 \\
\hline 5 & $7 e$ & $4-\mathrm{MeOC}_{6} \mathrm{H}_{4}$ & $\mathrm{CN}$ & 4- $\mathrm{MeOC}_{6} \mathrm{H}_{4}$ & 60 & B & 12 & 94 \\
\hline 6 & $7 f$ & 4- $\mathrm{MeOC}_{6} \mathrm{H}_{4}$ & $\mathrm{CN}$ & $4-\mathrm{ClC}_{6} \mathrm{H}_{4}$ & 60 & B & 15 & 70 \\
\hline 7 & $7 g$ & $4-\mathrm{MeOC}_{6} \mathrm{H}_{4}$ & $-\mathrm{N}\left(\mathrm{CH}_{2} \mathrm{CH}_{2}\right)_{2}$ & $\mathrm{Me}$ & 25 & A & 11 & 76 \\
\hline 8 & 7h & $4-\mathrm{MeOC}_{6} \mathrm{H}_{4}$ & $-\mathrm{N}\left(\mathrm{CH}_{2} \mathrm{CH}_{2}\right)_{2}$ & $-\mathrm{CH}=\mathrm{CHCOOH}$ & 25 & A & 56 & 85 \\
\hline 9 & $7 \mathbf{i}$ & $4-\mathrm{MeOC}_{6} \mathrm{H}_{4}$ & $-\mathrm{N}\left(\mathrm{CH}_{2} \mathrm{CH}_{2}\right)_{2}$ & $4-\mathrm{MeOC}_{6} \mathrm{H}_{4}$ & 60 & B & 45 & 79 \\
\hline 10 & $7 \mathbf{j}$ & $4-\mathrm{MeOC}_{6} \mathrm{H}_{4}$ & $-\mathrm{N}\left(\mathrm{CH}_{2} \mathrm{CH}_{2}\right)_{2}$ & $4-\mathrm{ClC}_{6} \mathrm{H}_{4}$ & 60 & B & 40 & 83 \\
\hline
\end{tabular}

a Isolated yield of (2-aryl-1,2,3-thiadiazol-5(2H)-ylidene)acetamides $\mathbf{7 a - j}$ after purification.<smiles>[R]C(=NN[Tl])C(N)=S</smiles>

$1 \mathrm{a}, \mathrm{e}$<smiles>O=C(O)CCCCCC(=O)O</smiles><smiles></smiles>

C: $(\mathrm{MeCO})_{2} \mathrm{O}(\mathbf{2 a})$,
Pyr, $115{ }^{\circ} \mathrm{C}$ $78-85 \%$

$8 \mathrm{Ar}=4-\mathrm{MeOC}_{6} \mathrm{H}_{4} \quad \mathrm{R}^{1}=\mathrm{CN}(\mathbf{a})$,<smiles>[R]=C[CH-]C(C)N1CCCC1</smiles>
(b)

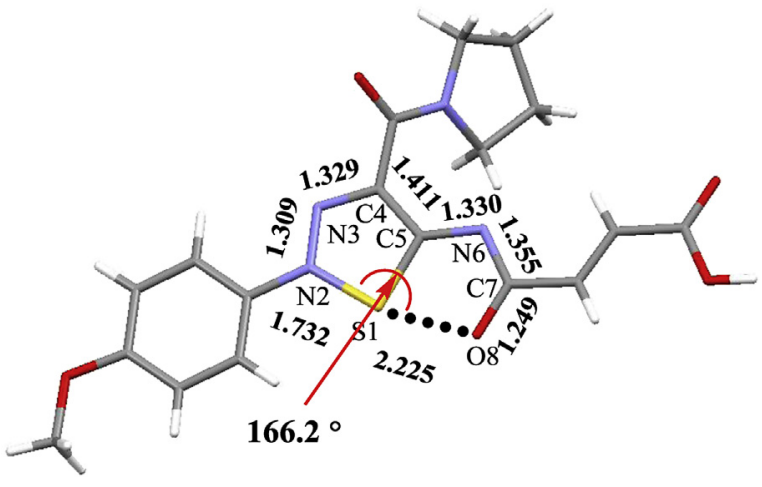

Fig. 3. Molecular structure of $\mathbf{7 h}$ (X-ray data).

Scheme 4 .

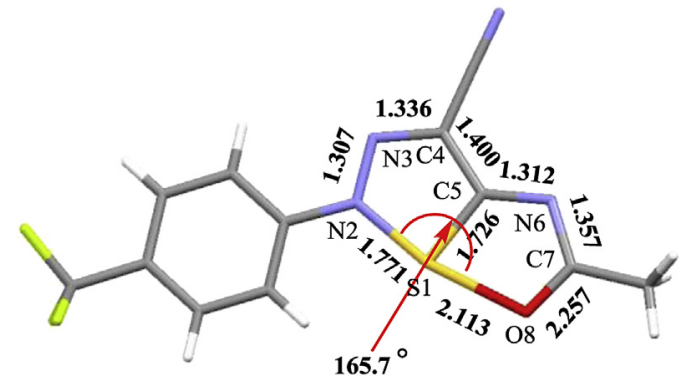

Fig. 1. Molecular structure of 7d (X-ray data).

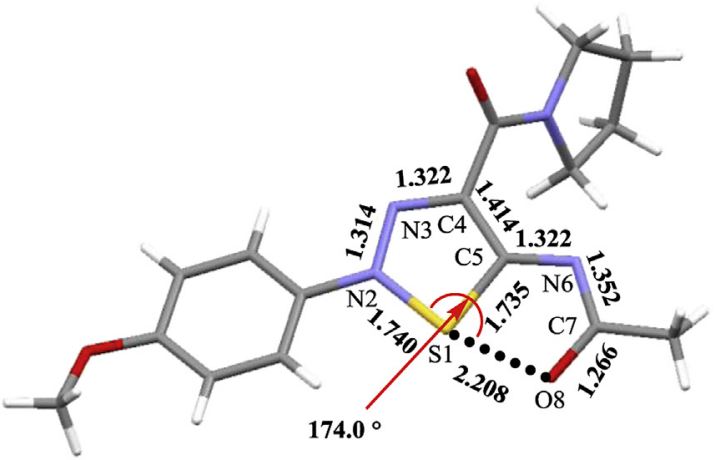

Fig. 2. Molecular structure of $\mathbf{7 g}$ (X-ray data).

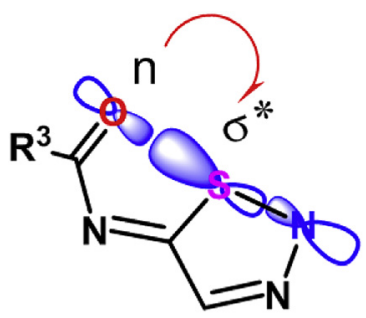

Fig. 4. Non-bonded $S \cdots O$ interaction due to $n \rightarrow \sigma^{*}$ orbital overlap effect in 1,2,3,thiadiazoles $7^{8 c}$

the difference in energies for two isomers. Energy differences $(\Delta E)$ calculated at B3LYP/6-31G* level of theory are collected in Table 2. We have found that the $Z$-isomers of compounds $\mathbf{7}$ with hypervalent thiadiazole sulfur atom were more stable than the $E$-isomers. The stabilization effect, quantitatively expressed via $\Delta E$, decreased in the row: $\mathbf{7 i}\left(\mathrm{R}^{3}=4-\mathrm{MeOC}_{6} \mathrm{H}_{4}\right)>\mathbf{7 h}\left(\mathrm{R}^{3}=\mathrm{CH}=\mathrm{CHCO}_{2} \mathrm{H}\right)>\mathbf{7} \mathbf{j}\left(\mathrm{R}^{3}=4-\right.$ $\left.\mathrm{ClC}_{6} \mathrm{H}_{4}\right)>7 \mathbf{a}\left(\mathrm{R}^{3}=\mathrm{Me}\right)$.

An additional factor increasing the stability of compounds 7 could be a stronger aromatic delocalization in heterocyclic fragments composing thiapentalene system. Aromaticity can be quantitatively described in terms of nuclear independent chemical shift (NICS). ${ }^{11}$ A number of extensive reviews ${ }^{11 b}$ focused on this topic were published in the last decade. Different variations of NICS indexes were proposed as a tool to measure aromaticity. NICS indices are the negative of magnetic shielding values computed at central points of rings and in the vicinity of molecules. Coordinates of ring centers can be deduced from the positions of atoms composing the ring or can be taken from Bader's AIM analysis (Atoms in Molecule). ${ }^{12}$ Terms of $\sigma$ - and $\pi$-orbitals in magnetic shielding can be calculated separately. $\operatorname{NICS}(0)_{\pi z z}$ index reflecting the term of $\pi$-bonds has shown the best correlation with experimentally 
Table 2

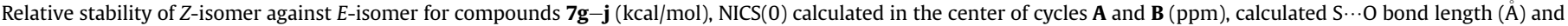
energy of non-covalent interaction S $\cdots \mathrm{O}$ (NBO method)

\section{Z-izomer}

\begin{tabular}{|c|c|c|c|c|c|c|c|}
\hline \multirow{2}{*}{ Entry } & \multirow{2}{*}{ Compound } & \multirow{2}{*}{$\Delta E,(\mathrm{kcal} / \mathrm{mol})$} & \multirow{2}{*}{\multicolumn{4}{|c|}{$Z$-isomer }} & \multirow{3}{*}{$\begin{array}{l}\text { E-isomer } \\
\mathrm{NICS}(0)^{\mathrm{A}}{ }_{\text {iso, }}(\mathrm{ppm})\end{array}$} \\
\hline & & & tovin & & & & \\
\hline 1 & & & & & 管 & & \\
\hline 2 & $7 \mathrm{~h}$ & $\begin{array}{r}0.523 \\
12.538\end{array}$ & $\begin{array}{l}-9.323 \\
-9.627\end{array}$ & $\begin{array}{l}-7.602 \\
-8.187\end{array}$ & $\begin{array}{l}2.231 \\
2.233\end{array}$ & $\begin{array}{l}25.97 \\
25.75\end{array}$ & $\begin{array}{l}-8.174 \\
-8.209\end{array}$ \\
\hline 3 & $7 \mathbf{i}$ & 12.742 & -8.823 & -7.425 & 2.223 & 26.76 & -8.486 \\
\hline 4 & $7 \mathbf{j}$ & 12.500 & -9.549 & -7.385 & 2.238 & 25.21 & -8.700 \\
\hline
\end{tabular}

measured aromaticity. ${ }^{11 \mathrm{~b}} \mathrm{NICS}(0)_{\text {iso, }}$ calculated in the plane of the ring and described the influence of both types of orbitals on aromaticity, also performed well and had a high correlation coefficient, $\mathrm{R}^{2}=0.946$. $^{11 \mathrm{a}}$

We have calculated $\operatorname{NICS}(0)_{\text {iso }}$ indices for compounds $\mathbf{7 g}-\mathbf{j}$ in geometrical centers of both five-membered atomic rings $\mathbf{A}$ and $\mathbf{B}$ at the B3LYP/6-31G* level of theory (Table 2). Calculated values were

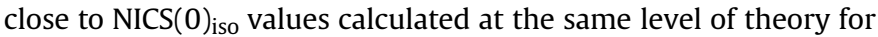
benzene $(-11.5 \mathrm{ppm})$ and naphthalene $(-9.9 \mathrm{ppm})^{11 \mathrm{c}}$ molecules. Thus, we concluded that the aromatic system was established in both cycles, A and B. But, no linear correlation between values of stabilization energy and $\operatorname{NICS}(0)_{\text {iso }}$ was found (Table 2 ). The loss of $\mathrm{S}$...O interaction led to the decrease in aromaticity of thiadiazole ring, since $\mathrm{NICS}(0)_{\text {iso }}$ values calculated for $E$-isomers were lower comparing to those of $Z$-isomers.

To evaluate the strength of the $n(\mathrm{O}) \rightarrow\left[\sigma^{*}(\mathrm{~S}-\mathrm{N})\right]$ interaction we have applied a second order perturbation theory analysis of Fock matrix on natural bond orbitals (NBO) basis. ${ }^{13}$ This method is used to calculate the energy of interaction between certain donor and acceptor in terms of bond orbitals. NBO analysis was performed at B3LYP/6-31G* level. The correlation between the stabilization energy $\Delta E$ and the energy of interaction between donor/acceptor orbitals, $E\left[n(\mathrm{O}) \rightarrow \sigma^{*}(\mathrm{SN})\right]$ was ambiguous also (Table 2).

To determine the participation of sulfur and oxygen atoms in the bicyclic aromatic system we calculated Wiberg bond indexes and the electron population of atoms S and $\mathrm{O}$ by applying NBO method (Table 3). Symbathic decrease in occupancy of lone pair of oxygen atom and increase of occupancy of vacant $\sigma^{*}(\mathrm{SN})$ orbital, and nonzero values of Wiberg bond indexes advocate the existence of dative $S \cdots O$ bond. AIM analysis has also confirmed the formation of $S$...O bond and a new ring: bond critical points of $(3,-1)$ type and ring critical point of $(3,+1)$ type were found for all listed compounds. The amount of electron density located in bond critical points is shown in Table 3. Thus, the formation of an aromatic-like $6 \mathrm{a} \lambda^{4}$-thiapentalene framework was confirmed.

Table 3

Wiberg bond indexes $n(\mathrm{~S} \cdots \mathrm{O})$, occupancy of $n(\mathrm{O})$ and $\sigma^{*}(\mathrm{SN})$ orbitals, obtained by NBO calculations, and the electron density $\rho$ in $(3,-1) \mathrm{S} \cdots \mathrm{O}$ bond critical point obtained by AIM calculations for 1 -oxa-6a $\lambda^{4}$-thia-3,5,6-triazapentalene $7 \mathbf{g}-\mathbf{j}$

\begin{tabular}{llllll}
\hline Entry & Compound & $n(\mathrm{~S} \cdots \mathrm{O})$ & $\begin{array}{l}\text { Occupancy } \sigma^{*} \\
(\mathrm{SN})\end{array}$ & $\begin{array}{l}\text { Occupancy } \\
n(\mathrm{O})\end{array}$ & $\rho(\mathrm{BCP}),($ a.u $)$. \\
\hline 1 & $\mathbf{7 g}$ & 0.2437 & 0.1909 & 1.7709 & $5.810 \cdot 10^{-2}$ \\
2 & $\mathbf{7 h}$ & 0.1617 & 0.1885 & 1.7730 & $5.842 \cdot 10^{-2}$ \\
3 & $\mathbf{7 i}$ & 0.2443 & 0.1949 & 1.7679 & $5.916 \cdot 10^{-2}$ \\
4 & $\mathbf{7 j}$ & 0.2372 & 0.1900 & 1.7730 & $5.734 \cdot 10^{-2}$ \\
\hline
\end{tabular}

The degree of electron density expansion from oxygen to sulfur atom may be quantitatively characterized by the covalence ratio factor $(\chi)$ via equation (Eq. 1), as previously introduced by $\mathrm{F}$. Weinhold and co-workers. ${ }^{8 \mathrm{a}, \mathrm{d}}$

$\chi=\frac{\left(R_{X}+R_{Y}\right)-d_{X Y}}{\left(R_{X}+R_{Y}\right)-\left(r_{X}+r_{Y}\right)} \leq 1$

where $R_{X}$ and $R_{y}$ stand for van der Waals radii and $r_{x}$ и $r_{y}$ for covalent radii of the interacting atoms; $d_{x y}$ is experimentally determined (or calculated) contact.

The expansion factors $(\chi)$ were calculated to be relatively high for compounds 7d,g,h:

$$
\begin{aligned}
& \chi_{\mathbf{7 d}}=\frac{(1.50+1.85)-2.108}{(1.50+1.85)-(0.66+1.02)}=0.74 \\
& \chi_{7 \mathbf{g}}=\frac{(1.50+1.85)-2.225}{(1.50+1.85)-(0.66+1.02)}=0.68
\end{aligned}
$$

$\chi_{\mathbf{7 h}}=\frac{(1.50+1.85)-2.113}{(1.50+1.85)-(0.66+1.02)}=0.74$

Summarizing the results of this computational study we suggest that the cooperative interplay of all reviewed factors could contribute to increased stability of (1,2,3-thiadiazol-5(2H)-ylidene) acetamides 7, but the formation of an $\mathrm{S} \cdots \mathrm{O}$ dative bond was the most important.

\section{Conclusion}

A new simple atom-economical method to obtain 5acyliminothiadiazoles is described. Acylation of arylhydrazonoethanethioamides did not stop at the formation of acyl derivatives as it was expected; instead, acylated hydrazonoethanethioamides were oxidized by atmospheric oxygen yielding 5-acylimino-2,5dihydro-1,2,3-thiadiazoles. The main factor controlling the direction of this reaction was the formation of an aromatic bicyclic system in final products.

Combined analysis of spectral and crystallographic data confirmed the existence of three-centered four electrons $\mathrm{N}-\mathrm{S}-\mathrm{O}$ bond. Computational methods applied to the problem have determined factors, responsible for enhanced stability of thiadiazoles 7. The most important was the formation of dative $S \cdots O$ 
contact. In turn, the formation of additional ring increased aromatic stability of thiadiazoles $\mathbf{7}$. The aromaticity of compounds 7 was close to the one of benzene/naphthalene molecules based on calculated $\operatorname{NICS}(0)$ iso values. The shift of electron density from oxygen to sulfur was evaluated by NBO method. The covalent character for the $\mathrm{S} \cdots \mathrm{O}$ bond was relatively high: Weinhold's covalency ratio factors were $0.67-0.74$. All descriptors advocate that obtained compounds 7 can be classified as new examples of $6 a \lambda^{4}$-thiapentalene systems with central hypervalent sulfur atom.

\section{Experimental section}

\subsection{General information and materials}

Melting points were determined with a Stuart SMP3 apparatus. ${ }^{1} \mathrm{H}$ NMR and ${ }^{13} \mathrm{C}$ NMR spectra were recorded on a Bruker Avance II (400 MHz for ${ }^{1} \mathrm{H}$ and $100.6 \mathrm{MHz}$ for ${ }^{13} \mathrm{C}$ ) spectrometer using DMSO$d_{6}$ and $\mathrm{CDCl}_{3}$ as solvents. Chemical shifts $(\delta)$ are reported in parts per million (ppm) relative to TMS in ${ }^{1} \mathrm{H}$ and ${ }^{13} \mathrm{C}$ spectra. Coupling constants $(J)$ values are given in Hertz. Mass spectra were performed on a Varian MAT 311A mass spectrometer using the electron impact ionization technique $\left(40-200{ }^{\circ} \mathrm{C}, 70 \mathrm{eV}\right)$. The IR data were recorded on a Bruker Alpha (NPVO, ZnSe) IR-Fur spectrometer. Elemental analyses were carried out using a CHNS/O analyzer Perkin-Elmer 2400 Series II instrument. Single crystal X-ray diffraction analyses were performed on an Xcalibur S CCD areadetector diffractometer (Mo $\mathrm{K}_{\alpha}$ irradiation, $\omega$-scanning with step $\left.1^{\circ}, 295(2) \mathrm{K}\right)$. Absorption correction not performed. Solution and refinement of structures were accomplished with SHELXTL program package. ${ }^{14}$

For 7d crystal system is orthorhombic, $a=8.6795(8) \AA$, $b=7.7947(5) \AA, c=40.653(5) \AA$, space group $P b c a$, Volume 2750.3(4) $\AA^{3}, Z=8, \quad \mu=0.273 \mathrm{~mm}^{-1}$. Reflections collected/independent/with $[I>2 \sigma(I)] \quad 7139 / 2686 / 1209, \quad R_{\text {int }}=0.0509$, completeness to $\theta=25.00^{\circ} 96.5 \%$. $S=1.005$, final $R$ indices: $R_{1}=0.0534$, $w R_{2}=0.0607[I>2 \sigma(I)], R_{1}=0.1448, w R_{2}=0.0693$ (all data). Largest diff. peak and hole: 0.246 and $0.190 \overline{\mathrm{e}}^{-3}$.

For $7 \mathrm{~g}$ crystal system is triclinic, $a=8.2623(8) \AA$, $b=8.4228(16) \AA, c=12.2293(16) \AA, \alpha=81.076(13)^{\circ}, \beta=88.581(10)^{\circ}$, $\gamma=80.413(12)^{\circ}$, space group $P-1$, Volume $829.0(2) \AA^{3}, Z=2$, $\mu=0.218 \mathrm{~mm}^{-1}$. Reflections collected/independent/with $[I>2 \sigma(I)]$ $6191 / 3987 / 1505, R_{\text {int }}=0.0480$, completeness to $\theta=28.28^{\circ} 97.1 \%$. $S=1.011$, final $R$ indices: $R_{1}=0.0508, \quad w R_{2}=0.1032 \quad[I>2 \sigma(I)]$, $R_{1}=0.1721, w R_{2}=0.1152$ (all data). Largest diff. peak and hole: 0.283 and $-0.206 \overline{\mathrm{e}}^{-3}$.

For 7h crystal system is triclinic, $a=8.289(2) \AA, b=8.6627(12) \AA$, $c=13.0570(14) \AA, \alpha=94.191(12)^{\circ}, \beta=93.649(16)^{\circ}, \gamma=99.640(16)^{\circ}$, space group $P-1$, Volume 919.1(3) $\AA^{3}, Z=2, \mu=0.216 \mathrm{~mm}^{-1}$. Reflections collected/independent/with $[I>2 \sigma(I)]$ 9038/5775/ 2453, $R_{\text {int }}=0.0315$, completeness to $\theta=26.00^{\circ} 98.5 \% . S=1.001$, final $R$ indices: $R_{1}=0.0487, w R_{2}=0.0806[I>2 \sigma(I)], R_{1}=0.1296$, $w R_{2}=0.0888$ (all data). Largest diff. peak and hole: 0.461 and $-0.419 \overline{\mathrm{e}} \AA^{-3}$.

CCDC 902766, 902767, and 912581 contains the supplementary crystallographic data for this paper. These data can be obtained free of charge from the Cambridge Crystallographic Data Centre via www.ccdc.cam.ac.uk/data_request/cif.

Chromatography purification compounds $\mathbf{7 a}-\mathbf{j}$ were done using silica gel $(0.035-0.070,60 \AA)$. The reactions were monitored on silica gel plates (Sorbfil UV-254) and visualization was effected by short wavelength UV light (254 nm). Solvents were dried and distilled according to the common procedure.

Arylhydrazonoethanethioamides $\mathbf{1}$ were prepared by the procedure reported in our previous articles. ${ }^{4}$

\subsection{General procedures for the synthesis of 5-acylimino-2,5- dihydro-1,2,3-thiadiazoles 7 and 1,2,3-thiadiazol-5(2H)-imi- nium bromide 8}

Procedure A. To a solution of arylhydrazonoethanethioamide $\mathbf{1}$ (1 $\mathrm{mmol}$ ) in $10 \mathrm{~mL}$ anhydrous pyridine was added anhydride 2 ( $2 \mathrm{mmol}$ ) with intensive stirring. The resulting mixture was stirred at room temperature until starting hydrazone completely consumed (TLC). The solution was poured into a mixture of water with ice. The formed precipitate was filtered off, washed with water, and dried.

Procedure $B$. To a solution of arylhydrazonoethanethioamide $\mathbf{1}$ ( $1 \mathrm{mmol}$ ) in $10 \mathrm{~mL}$ anhydrous pyridine was added acyl chloride $\mathbf{3}$ ( $2 \mathrm{mmol}$ ) with intensive stirring. The resulting mixture was stirred at $60{ }^{\circ} \mathrm{C}$ until the hydrazone was completely consumed. The solution was cooled to room temperature and poured into a mixture of water with ice. The solid was filtered off, washed with water, and dried.

Procedure C. A solution of bromine $(0.4 \mathrm{~mL}, 8 \mathrm{mmol})$ in $5 \mathrm{~mL}$ of acetic acid was added with stirring to a solution of arylhydrazonoethanethioamide $1(2 \mathrm{mmol})$ in $100 \mathrm{~mL}$ of acetic acid at $40{ }^{\circ} \mathrm{C}$. The mixture was allowed to cool to room temperature and stirred for $5 \mathrm{~h}$. The precipitate was filtered off and recrystallized from ethanol.

Procedure $D$. To the mixture of 2-aryl-2,5-dihydro-[1,2,3]-thiadiazoliminium bromide $8(1 \mathrm{mmol})$ in $4 \mathrm{~mL}$ pyridine was added acetic anhydride $(0.5 \mathrm{~mL}, 5 \mathrm{mmol})$. The reaction mixture was refluxed for $2 \mathrm{~h}$ (TLC) and then was poured into water with ice. The precipitate was filtered off, washed with water, and dried.

4.2.1. N-[4-Cyano-2-(4-methoxyphenyl)-1,2,3-thiadiazol-5(2H)-ylidene]acetamide (7a). Procedure A gave the title compound 7a (170 $\mathrm{mg}, 62 \%)$ and procedure D gave the title compounds 7a (214 mg, yield 78\%) as a yellow solid, mp $108-109{ }^{\circ} \mathrm{C}$; [Found: C, 52.8; $\mathrm{H}, 3.5 ; \mathrm{N}, 20.3 ; \mathrm{S}, 11.9 . \mathrm{C}_{12} \mathrm{H}_{10} \mathrm{~N}_{4} \mathrm{O}_{2} \mathrm{~S}$ requires $\mathrm{C}$, 52.54; $\mathrm{H}, 3.67$; N, 20.43; S, 11.69\%); $\nu_{\max } 2238(\mathrm{C} \equiv \mathrm{N}), 1604(\mathrm{C}=\mathrm{O}) \mathrm{cm}^{-1} ; \delta_{\mathrm{H}}$ (400 MHz, DMSO-d $) 2.56$ (3H, s, COMe), 3.87 (3H, s, OMe), 7.09 and 7.77 (4H, AA'XX', J $8.8 \mathrm{~Hz}, \mathrm{ArH}) ; \delta_{\mathrm{C}}\left(100.6 \mathrm{MHz}\right.$, DMSO-d $\left.\mathrm{d}_{6}\right) 182.2$, $167.5,160.0,133.4,122.0,117.9,115.2,112.2,55.7,23.3 ; m / z, 274\left(\mathrm{M}^{+}\right.$, $100 \%)$.

4.2.2. N-(4-Cyano-2-phenyl-1,2,3-thiadiazol-5(2H)-ylidene)acetamide (7b). Procedure A gave the title compound $\mathbf{7 b}(132 \mathrm{mg}, 54 \%)$ as a yellow solid, mp $110-111{ }^{\circ} \mathrm{C}$; [Found: C, 54.3; H, 3.4; N, 23.1; S, 13.3. $\mathrm{C}_{11} \mathrm{H}_{8} \mathrm{~N}_{4} \mathrm{OS}$ requires $\left.\mathrm{C}, 54.09 ; \mathrm{H}, 3.30 ; \mathrm{N}, 22.94 ; \mathrm{S}, 13.13 \%\right] ; \nu_{\max }$ $2234(\mathrm{C} \equiv \mathrm{N}), 1591(\mathrm{C}=\mathrm{O}) \mathrm{cm}^{-1} ; \delta_{\mathrm{H}}\left(400 \mathrm{MHz}, \mathrm{DMSO}-d_{6}\right) 7.86-7.90$ (2H, m, ArH), 7.69-7.56 (2H, m, ArH), 7.54-7.48 (1H, m, ArH), 2.58 $(3 \mathrm{H}, \mathrm{s}, \mathrm{COMe}) ; \delta_{\mathrm{C}}\left(100.6 \mathrm{MHz}\right.$, DMSO- $\left.d_{6}\right) 182.0,168.9,140.5,130.7$, $129.9,120.8,119.4,112.5,23.8$; MS (EI) $m / z 244\left(\mathrm{M}^{+}, 100 \%\right)$.

4.2.3. $\mathrm{N}$-(2-(4-Chlorophenyl)-4-cyano-1,2,3-thiadiazol-5(2H)-ylidene)acetamide $(\mathbf{7 c})$. Procedure A gave the title compound $\mathbf{7 c}$ (192 mg, 69\%) as a yellow solid, $\mathrm{mp} 124-125^{\circ} \mathrm{C}$; [Found: $\mathrm{C} 47.7 ; \mathrm{H}$ 2.3; N 20.3; $\mathrm{S} 11.6$. $\mathrm{C}_{11} \mathrm{H}_{7} \mathrm{ClN}_{4} \mathrm{OS}$ requires $\mathrm{C} 47.40 ; \mathrm{H} \mathrm{2.53;} \mathrm{N} \mathrm{20.10;} \mathrm{S}$ $11.50 \%] ; \nu_{\max } 2236(\mathrm{C} \equiv \mathrm{N}), 1595(\mathrm{C}=\mathrm{O}) \mathrm{cm}^{-1} ; \delta_{\mathrm{H}}(400 \mathrm{MHz}$, DMSO$\left.d_{6}\right) 7.59$ and $7.89\left(4 \mathrm{H}, \mathrm{AA}^{\prime} \mathrm{XX}^{\prime}, J 8.0 \mathrm{~Hz}, \mathrm{ArH}\right), 2.57(3 \mathrm{H}, \mathrm{s}, \mathrm{COMe}) ; \delta_{\mathrm{C}}$ $\left(100.6 \mathrm{MHz}\right.$, DMSO- $\left.d_{6}\right)$ 183.0, 168.4, 139.3, 134.2, 130.6, 122.4, 119.6, 112.4, 23.4; MS (EI) $m / z 278\left(\mathrm{M}^{+}, 100 \%\right)$.

4.2.4. N-[4-Cyano-2-[4-(trifluoromethyl)phenyl]-1,2,3-thiadiazol$5(2 \mathrm{H})$-ylidene acetamide ( $7 \mathbf{d})$. Procedure A gave the title compound 7d (193 mg, 62\%) as a yellow solid, $\mathrm{mp} 116-117{ }^{\circ} \mathrm{C}$; [Found: C, 46.3; $\mathrm{H}, 2.4 ; \mathrm{N}, 18.2 ; \mathrm{S}, 10.4 . \mathrm{C}_{12} \mathrm{H}_{7} \mathrm{~F}_{3} \mathrm{~N}_{4} \mathrm{OS}$ requires $\mathrm{C}, 46.16 ; \mathrm{H}, 2.26 ; \mathrm{N}$, $17.94 ; \mathrm{S}, 10.27 \%] ; \nu_{\max } 2240(\mathrm{C} \equiv \mathrm{N}), 1591(\mathrm{C}=\mathrm{O}) \mathrm{cm}^{-1} ; \delta_{\mathrm{H}}(400 \mathrm{MHz}$, DMSO- $\left.d_{6}\right) 7.89$ and $8.12\left(4 \mathrm{H}, \mathrm{AA}^{\prime} \mathrm{XX}^{\prime}, J 8.8 \mathrm{~Hz}, \mathrm{ArH}\right), 2.61(3 \mathrm{H}, \mathrm{s}$, COMe); $\delta_{\mathrm{C}}\left(100.6 \mathrm{MHz}, \mathrm{DMSO}-d_{6}\right) 182.9,168.0,142.8,128.8$ (q, $J$ 
$32 \mathrm{~Hz}), 127.4,123.3$ (q, J $270 \mathrm{~Hz}), 120.6,119.9,111.7,23.3$; MS (EI) $m / z$ $312\left(\mathrm{M}^{+}, 100 \%\right)$.

4.2.5. N-(4-Cyano-2-(4-methoxyphenyl)-1,2,3-thiadiazol-5(2H)-ylidene)-4-methoxybenzamide (7e). Procedure B gave the title compound 7e (259 mg, $94 \%$ ) as a yellow solid, $\mathrm{mp} 206-207^{\circ} \mathrm{C}$; [Found: C, 51.4; $\mathrm{H} 2.3$; N 15.2; $\mathrm{S}$ 8.7. $\mathrm{C}_{16} \mathrm{H}_{8} \mathrm{Cl}_{2} \mathrm{~N}_{4} \mathrm{O}_{2} \mathrm{~S}$ requires $\mathrm{C}$, 51.21; $\mathrm{H}, 2.15$; N, 14.93; S, 8.55\%]; $\nu_{\max } 2240(\mathrm{C} \equiv \mathrm{N}), 1590(\mathrm{C}=\mathrm{O}) ; \delta_{\mathrm{H}}(400 \mathrm{MHz}$, DMSO- $\left.d_{6}\right) 8.45$ and $7.26\left(4 \mathrm{H}, \mathrm{AA}^{\prime} \mathrm{XX}^{\prime}, J 8.8 \mathrm{~Hz}, \mathrm{ArH}\right), 7.96$ and 7.21 (4H, $\left.\mathrm{AA}^{\prime} \mathrm{XX}^{\prime}, J 9.2 \mathrm{~Hz}, \mathrm{ArH}\right), 4.05$ (3H, s, OMe), 4.02 (3H, s, OMe); $\delta_{\mathrm{C}}$ $\left(100.6 \mathrm{MHz}\right.$, DMSO-d $\left.d_{6}\right) 181.8,164.0,160.5,160.2,141.9,135.0,132.1$, $127.8,122.7,115.9,114.9,113.2,56.2,56.1$; MS (EI) $m / z 366\left(\mathrm{M}^{+}, 2 \%\right)$.

4.2.6. $\mathrm{N}$-(2-(4-Methoxyphenyl)-4-cyano-1,2,3-thiadiazol-5(2H)-ylidene) 4-chlorobenzamide ( $7 \boldsymbol{f})$. Procedure B gave the title compound 7f $(353 \mathrm{mg}, 70 \%)$ as a yellow solid, $\mathrm{mp} 204-205^{\circ} \mathrm{C}$; [Found: C, 55.3; $\mathrm{H}, 3.3 ; \mathrm{N}, 15.3 ; \mathrm{S}, 8.8 . \mathrm{C}_{17} \mathrm{H}_{11} \mathrm{ClN}_{4} \mathrm{O}_{2} \mathrm{~S}$ requires $\mathrm{C}, 55.06 ; \mathrm{H}, 2.99 ; \mathrm{N}$, $15.11 ; \mathrm{S}, 8.65] ; \nu_{\max } 2237(\mathrm{C} \equiv \mathrm{N}), 1584(\mathrm{C}=\mathrm{O}) \mathrm{cm}^{-1} ; \delta_{\mathrm{H}}(400 \mathrm{MHz}$, DMSO- $\left.d_{6}\right), 8.33$ and $7.58\left(4 \mathrm{H}, \mathrm{AA}^{\prime} \mathrm{XX}^{\prime}, J 8.8 \mathrm{~Hz}, \mathrm{ArH}\right), 7.83$ and 7.12 $\left(4 \mathrm{H}, \mathrm{AA}^{\prime} \mathrm{XX}^{\prime}, J 9.2 \mathrm{~Hz}, \mathrm{ArH}\right), 3.88$ (3H, s, OMe); $\delta_{\mathrm{C}}(100.6 \mathrm{MHz}$, DMSO$\left.d_{6}\right) 174.5,168.3,160.2,138.4,133.3,130.9,130.6,129.0,122.1,119.1$, 115.2, 111.8, 55.6; MS (EI) $m / z 370\left(\mathrm{M}^{+}, 24 \%\right)$.

4.2.7. N-(2-(4-Methoxyphenyl)-4-(pyrrolidine-1-carbonyl)-1,2,3thiadiazol-5(2H)-ylidene)acetamide ( $\mathbf{7 g}$ ). Procedure A gave the title compound $7 \mathbf{g}(223 \mathrm{mg}, 76 \%)$, procedure D gave the title compound $7 \mathbf{g}(294 \mathrm{mg}, 85 \%)$ as a yellow solid, $\mathrm{mp} 122-123^{\circ} \mathrm{C}$. [Found: C, 56.2; $\mathrm{H}, 5.2 ; \mathrm{N}, 16.5 ; \mathrm{S}, 9.2 . \mathrm{C}_{16} \mathrm{H}_{18} \mathrm{~N}_{4} \mathrm{O}_{3} \mathrm{~S}$ requires $\mathrm{C}, 55.48 ; \mathrm{H}, 5.24 ; \mathrm{N}$, 16.17; S, 9.26]; $\nu_{\max } 2973,2877(\mathrm{CH}), 1606(\mathrm{C}=\mathrm{O}) \mathrm{cm}^{-1} ; \delta_{\mathrm{H}}$ (400 MHz, DMSO-d $\left.d_{6}\right) 7.72$ and $7.06\left(4 \mathrm{H}, \mathrm{AA}^{\prime} \mathrm{XX}^{\prime}, J 8.8 \mathrm{~Hz}, \mathrm{ArH}\right), 3.85$ ( $3 \mathrm{H}, \mathrm{s}, \mathrm{OMe}), 3.62\left(2 \mathrm{H}, \mathrm{t}, J 6.8 \mathrm{~Hz}, \mathrm{CH}_{2}\right), 3.48\left(2 \mathrm{H}, \mathrm{t}, J 6.8 \mathrm{~Hz}, \mathrm{CH}_{2}\right)$, $2.46(3 \mathrm{H}, \mathrm{s}, \mathrm{Me}), 1.94-2.02\left(4 \mathrm{H}, \mathrm{m}, \mathrm{CH}_{2}\right) ; \delta_{\mathrm{C}}\left(100.6 \mathrm{MHz}, \mathrm{DMSO}-d_{6}\right)$ 181.2, 163.9, 159.8, 159.6, 140.9, 134.2, 122.0, 115.6, 56.0, 47.9, 46.3, 25.9, 24.3, 23.9; MS (EI) $m / z 346\left(\mathrm{M}^{+}, 11 \%\right)$.

4.2.8. 4-(2-(4-Methoxyphenyl)-4-(pyrrolidine-1-carbonyl)-1,2,3thiadiazol-5(2H)-ylideneamino)-4-oxobut-2-enoic acid(7h). Procedure A gave the title compound $\mathbf{7 h}$ (342 $\mathrm{mg}, 85 \%$ ) as a yellow solid, $\mathrm{mp}$ 207-208 ${ }^{\circ} \mathrm{C}$. [Found: $\mathrm{C}, 53.9 ; \mathrm{H}, 4.7 ; \mathrm{N}, 13.8 ; \mathrm{S}, 8.1 . \mathrm{C}_{18} \mathrm{H}_{18} \mathrm{~N}_{4} \mathrm{O}_{5} \mathrm{~S}$ requires C, 53.72; H, 4.51; N, 13.92; S, 7.97]; $\delta_{\mathrm{H}}\left(400 \mathrm{MHz}, \mathrm{DMSO}-d_{6}\right)$ $12.56(1 \mathrm{H}, \mathrm{s}, \mathrm{OH}), 7.26$ and $7.03\left(4 \mathrm{H}, \mathrm{AA}^{\prime} \mathrm{XX}^{\prime}, J 8.7 \mathrm{~Hz}, \mathrm{ArH}\right), 6.62$ and $6.35(2 \mathrm{H}, \mathrm{AX}, J 6.2 \mathrm{~Hz}, 2 \mathrm{CH}), 3.75(3 \mathrm{H}, \mathrm{s}, \mathrm{OMe}), 3.35-3.48\left(4 \mathrm{H}, \mathrm{m}, \mathrm{CH}_{2}\right)$, $1.59-1.72\left(4 \mathrm{H}, \mathrm{m}, \mathrm{CH}_{2}\right) ; \delta_{\mathrm{C}}\left(100.6 \mathrm{MHz}\right.$, DMSO- $\left.d_{6}\right) 173.9,167.1,164.4$, 160.3, 159.8, 142.6, 137.2, 134.5, 133.6, 122.7, 116.1, 56.5, 48.3, 46.8, 26.4, 24.7; MS (EI) $m / z 402\left(\mathrm{M}^{+}, 6 \%\right)$.

4.2.9. N-(2-(4-Methoxyphenyl)-4-(pyrrolidine-1-carbonyl)-1,2,3thiadiazol-5(2H)-ylidene)-4-methoxybenzamide (7i). Procedure B gave the title compound $7 \mathbf{i}$ (346 $\mathrm{mg}, 79 \%$ ) as a yellow solid, $\mathrm{mp}$ 180-181 ${ }^{\circ} \mathrm{C}$. [Found: C, 60.4; $\mathrm{H}, 5.2 ; \mathrm{N}, 12.6 ; \mathrm{S}, 7.5 . \mathrm{C}_{22} \mathrm{H}_{22} \mathrm{~N}_{4} \mathrm{O}_{4} \mathrm{~S}$ requires $\mathrm{C}, 60.26 ; \mathrm{H}, 5.06 ; \mathrm{N}, 12.78 ; \mathrm{S}, 7.31$ ]; $\delta_{\mathrm{H}}\left(400 \mathrm{MHz}\right.$, DMSO- $\left.d_{6}\right)$ 8.23 and $7.05\left(4 \mathrm{H}, \mathrm{AA}^{\prime} \mathrm{XX}^{\prime}, J 8.9 \mathrm{~Hz}, \mathrm{ArH}\right), 7.75$ and $7.02\left(4 \mathrm{H}, \mathrm{AA}^{\prime} \mathrm{XX}^{\prime}, J\right.$ $9.2 \mathrm{~Hz}, \mathrm{ArH}), 3.88$ (3H, s, OMe), 3.86 (3H, s, OMe), $3.68(2 \mathrm{H}, \mathrm{t}, J$ $\left.6.7 \mathrm{~Hz}, \mathrm{CH}_{2}\right), 3.58\left(2 \mathrm{H}, \mathrm{t}, J 6.6 \mathrm{~Hz}, \mathrm{CH}_{2}\right), 1.96-2.05\left(4 \mathrm{H}, \mathrm{m}, \mathrm{CH}_{2}\right) ; \delta_{\mathrm{C}}$ $\left(100.6 \mathrm{MHz}\right.$, DMSO- $\left.d_{6}\right) 174.8,164.4,163.5,159.8,159.6,141.5,134.3$, 131.6, 125.9, 122.0, 115.7, 114.7, 56.1, 56.0, 48.0, 46.5, 24.4, 26.1; MS (EI) $\mathrm{m} / \mathrm{z} 438\left(\mathrm{M}^{+}, 4 \%\right)$.

4.2.10. N-(2-(4-Methoxyphenyl)-4-(pyrrolidine-1-carbonyl)-1,2,3thiadiazol-5(2H)-ylidene)-4-chlorobenzamide ( $7 \mathbf{j})$. Procedure B gave the title compound $7 \mathbf{j}$ (367 $\mathrm{mg}, 83 \%$ ) as a yellow solid, mp 275-276 ${ }^{\circ} \mathrm{C}$. [Found: $\mathrm{C}, 56.9 ; \mathrm{H}, 4.5 ; \mathrm{N}, 12.6 ; \mathrm{S}, 7.5 . \mathrm{C}_{21} \mathrm{H}_{19} \mathrm{ClN}_{4} \mathrm{O}_{3} \mathrm{~S}$ requires $\mathrm{C}, 56.95 ; \mathrm{H}, 4.32 ; \mathrm{N}, 12.65 ; \mathrm{S}, 7.24] ; \delta_{\mathrm{H}}\left(400 \mathrm{MHz}\right.$, DMSO- $\left.d_{6}\right)$ 8.23 and $7.63\left(4 \mathrm{H}, \mathrm{AA}^{\prime} \mathrm{XX}^{\prime}, J 8.7 \mathrm{~Hz}, \mathrm{ArH}\right), 7.80$ and $7.13\left(4 \mathrm{H}, \mathrm{AA}^{\prime} \mathrm{XX}^{\prime}, J\right.$ $9.2 \mathrm{~Hz}, \mathrm{ArH}), 3.84(3 \mathrm{H}, \mathrm{s}, \mathrm{OMe}), 3.64\left(2 \mathrm{H}, \mathrm{t}, J 6.5 \mathrm{~Hz}, \mathrm{CH}_{2}\right), 3.55(2 \mathrm{H}, \mathrm{t}$, $\left.J 6.2 \mathrm{~Hz}, \mathrm{CH}_{2}\right), 1.87-1.99\left(4 \mathrm{H}, \mathrm{m}, \mathrm{CH}_{2}\right) ; \delta_{\mathrm{C}}\left(100.6 \mathrm{MHz}, \mathrm{DMSO}-d_{6}\right)$
$174.4,164.8,160.0,159.6,142.2,138.2,134.3,132.5,131.2,129.3$, 122.3, 115.8, 56.2, 47.9, 46.4, 26.0, 24.3; MS (EI) $m / z 442\left(\mathrm{M}^{+}, 5 \%\right)$.

4.2.11. 4-Cyano-2-(4-methoxyphenyl)-1,2,3-thiadiazol-5(2H)-iminium bromide $(\mathbf{8 a})$. Procedure $\mathrm{C}$ gave the title compound $\mathbf{8 a}$ (459 $\mathrm{mg}, 74 \%$ ). as a yellow solid, $\mathrm{mp} 134-135^{\circ} \mathrm{C}$. [Found: $\mathrm{C} 38.2 ; \mathrm{H}$ 2.9; $\mathrm{N}$ 17.5; $\mathrm{S} 10.2$. $\mathrm{C}_{10} \mathrm{H}_{9} \mathrm{BrN}_{4} \mathrm{OS}$ requires $\mathrm{C} 38.35 ; \mathrm{H} 2.90 ; \mathrm{N} 17.89 ; \mathrm{S}$ $10.24] ; \delta_{\mathrm{H}}\left(400 \mathrm{MHz}, \mathrm{CDCl}_{3}\right) 10.55\left(2 \mathrm{H}, \mathrm{br} \mathrm{s}, \mathrm{NH}_{2}\right), 7.67$ and $7.06(4 \mathrm{H}$, $\left.\mathrm{AA}^{\prime} \mathrm{XX}^{\prime}, \mathrm{J} 8.9 \mathrm{~Hz}, \mathrm{ArH}\right), 3.91$ (3H, s, OMe). (100.6 MHz, $\left.\mathrm{CDCl}_{3}\right)$ 170.7, $161.9,132.6,122.4,115.7,109.7,100.1,56.0$.

4.2.12. 2-(4-Methoxyphenyl)-4-(pyrrolidine-1-carbonyl)-1,2,3thiadiazol-5(2H)-iminium bromide $(\boldsymbol{8 b})$. Procedure $\mathrm{C}$ gave the title compound $8 \mathbf{a}(483 \mathrm{mg}, 63 \%)$ as a yellow solid, mp $232-233{ }^{\circ} \mathrm{C}$. [Found: $\mathrm{C} 43.8 ; \mathrm{H} 4.6$; $\mathrm{N} 14.7 ; \mathrm{S}$ 7.5. $\mathrm{C}_{14} \mathrm{H}_{17} \mathrm{BrN}_{4} \mathrm{O}_{2} \mathrm{~S}$ requires $\mathrm{C} 43.64$; $\mathrm{H} 4.45$; N 14.54; S 8.32]; $\delta_{\mathrm{H}}\left(400 \mathrm{MHz}, \mathrm{DMSO}-d_{6}\right) 10.46(1 \mathrm{H}, \mathrm{s}, \mathrm{NH})$, $10.01(1 \mathrm{H}, \mathrm{s}, \mathrm{NH}), 7.65$ and $7.07\left(4 \mathrm{H}, \mathrm{AA}^{\prime} \mathrm{XX}^{\prime}, J 9.0 \mathrm{~Hz}, \mathrm{ArH}\right)$, 3.98-3.95 (2H, m, CH $), 3.65-3.63\left(2 \mathrm{H}, \mathrm{m}, \mathrm{CH}_{2}\right), 2.05-2.02(2 \mathrm{H}, \mathrm{m}$, $\left.\mathrm{CH}_{2}\right), 1.90-1.95\left(2 \mathrm{H}, \mathrm{m}, \mathrm{CH}_{2}\right) ; \delta_{\mathrm{C}}\left(100.6 \mathrm{MHz}\right.$, DMSO- $\left.d_{6}\right) 171.5,160.3$, 159.4, 133.3, 132.9, 122.3, 115.8, 56.2, 49.3, 47.6, 26.5, 27.6.

\subsection{Computational details}

All calculations have been done with a help of G09 2 suit. ${ }^{15}$ Structures were initially optimized at B3LYP/6-31G* level of theory. All located points had a minima character according to Hessian calculation. An NBO analysis was performed at the same level of theory by calling appropriate module, implemented in G09. ${ }^{16}$ NICS values were calculated with GIAO approach ${ }^{17}$ and using 6-31G* basis set and B3LYP hybrid functional on ring geometric centers. Obtained B3LYP/6-31G* wave functions were studied by AIM method with the help of AIMAll software. ${ }^{18}$

\section{Acknowledgements}

The authors thank the Russian Foundation for Basic Research for financial support (grant RFBR \# 11-03-00579_a, RFBR \# 10-0396084-r_ural_a, RFBR \# 12-03-31574 mol_a). J.O.S. personally thanks Prof. Arvi Rauk (University of Calgary, Canada) for assistance. J.O.S. also thanks Compute Canada-Calcul Canada and Western Canada Research Grid for provided computational resources.

\section{Supplementary data}

Supplementary data related to this article can be found at http:// dx.doi.org/10.1016/j.tet.2013.06.071. These data include MOL files and InChiKeys of the most important compounds described in this article.

\section{References and notes}

1. (a) Belskaya, N. P.; Dehaen, W.; Bakulev, V. A. Arkivoc 2010, i, 275-332; (b) Gil M. J.; Reliquet, A.; Meslin, J. C. Phosphorus, Sulfur Silicon Relat. Elem. 1997, 126 39-52; (c) Belskaia, N. P.; Deryabina, T. G.; Koksharov, A. V.; Kodess, M. I.; Dehaen, W.; Lebedev, A. T.; Bakulev, V. A. Tetrahedron Lett. 2007, 48, 9128-9131; (d) Bel'skaia, N. P.; Koksharov, A. V.; Deryabina, T. G.; Bakulev, V. A. Chem Heterocycl. Compd. 2010, 46, 1156-1157.

2. (a) Sztanke, K.; Rzymowska, J.; Niemczyk, M.; Dybala, I.; Koziol, A. E. Eur. J. Med Chem. 2006, 41, 539-547; (b) Hunt, J. T.; Mitt, T.; Borzilleri, R.; Gullo-Brown, J.; Fargnoli, J.; Fink, B.; Han, W.-C.; Mortillo, S.; Vite, G.; Wautlet, B.; Wong, T.; Yu, C.; Zheng, X.; Bhide, R. J. Med. Chem. 2004, 47, 4054-4059; (c) Singh, S.; Husain, K.; Athar, F.; Azam, A. Eur. J. Pharm. Sci. 2005, 25, 255-262; (d) Sztanke, K.; Fidecka, S.; Kedzierska, E.; Karczmarzyk, Z.; Pihlaja, K.; Matosiuk, D. Eur. J. Med. Chem. 2005, 40, 127-134

3. Belskaya, N. P.; Bolgova, A. I.; Kondrat'eva, M. L.; Eltsov, O. S.; Bakulev, V. A. Russ Chem. Bull. 2011, 60, 896-900.

4. Vasil'eva, M. L.; Mukhacheva, M. V.; Bel'skaya, N. P.; Bakulev, V. A.; Anderson, R J.; Groundwater, P. V. Russ. J. Org. Chem. 2004, 40, 818-828. 
5. Kondrat'eva, M. L.; Bel'skaia, N. P.; Bakulev, V. A. Russ. J. Org. Chem. 2006, 42, 1192-1199.

6. Cordero, B.; Gomez, V.; Platero-Prats, A. E.; Reves, M.; Echeverria, J.; Cremades, E.; Barragan, F.; Alvarez, S. Dalton Trans. 2008, 2832-2838.

7. (a) L'abbe, G.; Dehaen, W.; Bastin, L.; Declercq, J.-P.; Feneau-Dupont, J. J. Heterocycl. Chem. 1992, 29, 461-465; (b) Morel, G.; Marchand, E.; Sinbandhit, S.; Toupet, L. Heteroat. Chem. 2003, 14, 95-105; (c) Tellez, F.; Cruz, A.; LopezSandoval, H.; Ramos-Garcia, I.; Gayosso, M.; Castillio-Sierra, R. N.; Paz-Michel, B.; Noth, H.; Flores-Parra, A.; Contreras, R. Eur. J. Org. Chem. 2004, 4203-4214.

8. (a) Minkin, V. I.; Minyaev, R. M. Chem. Rev. 2001, 101, 1247-1265; (b) Iwaoka, M.; Takemoto, S.; Okada, M.; Tomoda, S. Bull. Chem. Soc. Jpn. 2002, 75, 1611-1625; (c) Nagao, Y.; Hirata, T.; Goto, S.; Sano, S.; Kakehi, A.; Iizuka, K.; Shiro, M. J. Am. Chem. Soc. 1998, 120, 3104-3110; (d) Reed, A. E.; Curtiss, L. A.; Weinhold, F. Chem. Rev. 1988, 88, 899-926; (e) Rasovic, A.; Steel, P. J.; Kleinpeter, E.; Marcovic, R. Tetrahedron 2007, 63, 1937-1945; (f) Wu, S.; Greer, A. J. Org. Chem. 2000, 65, 4883-4887; (g) Pena-Hueso, A.; Tellez, F.; Vieto-Pena, R.; Esquivel, R. O.; Esparza-Ruiz, A.; Ramos-Garcia, I.; Contreras, R.; Barba-Behrens, N.; Flores-Parra, A. J. Mol. Struct. 2010, 984, 409-415.

9. (a) Dane, E. L.; King, S. B.; Swager, T. M. J. Am. Chem. Soc. 2010, 132, 7758-7768; (b) Poater, J.; Casanovas, J.; Sola, M.; Aleman, C. J. Phys. Chem. A 2010, 114, 1023-1028.

10. (a) Grabowski, S. J. J. Mol. Model. 2012, 33, 1-9; (b) Wenhold, F. J. J. Comput. Chem. 2012, 33, 2440-2449.

11. (a) Fallah-Bagher-Shaidaei, H.; Wannere, C. S.; Corminboeuf, C.; Puchta, R.; Schleyer, P. V. R. Org. Lett. 2006, 8, 863-866; (b) Chen, Z.; Wannere, C. S.; Corminboeuf, C.; Puchta, R.; Schleyer, P. V. R. Chem. Rev. 2005, 105,
3842-38881; (c) Schleyer, P. V. R.; Maerker, C.; Dransfeld, A.; Jiao, H.; Van Eikema Hommes, N. J. R. J. Am. Chem. Soc. 1996, 118, 6317-6318.

12. Bader, R. F. W. Chem. Rev. 1991, 91 893-928.

13. Weinhold, F. J. Comput. Chem. 2012, 33, 2363-2379.

14. Sheldrick, G. M. Acta Crystallogr. 2007, A64, 112-122.

15. Frisch, M. J.; Trucks, G. W.; Schlegel, H. B.; Scuseria, G. E.; Robb, M. A.; Cheeseman, J. R.; Scalmani, G.; Barone, V.; Mennucci, B.; Petersson, G. A.; Nakatsuji, H.; Caricato, M.; Li, X.; Hratchian, H. P.; Izmaylov, A. F.; Bloino, J.; Zheng, G.; Sonnenberg, J. L.; Hada, M.; Ehara, M.; Toyota, K.; Fukuda, R.; Hasegawa, J.; Ishida, M.; Nakajima, T.; Honda, Y.; Kitao, O.; Nakai, H.; Vreven, T.; Montgomery, J. A., Jr.; Peralta, J. E.; Ogliaro, F.; Bearpark, M.; Heyd, J. J.; Brothers, E.; Kudin, K. N.; Staroverov, V. N.; Kobayashi, R.; Normand, J.; Raghavachari, K.; Rendell, A.; Burant, J. C.; Iyengar, S. S.; Tomasi, J.; Cossi, M.; Rega, N.; Millam, J. M.; Klene, M.; Knox, J. E.; Cross, J. B.; Bakken, V.; Adamo, C.; Jaramillo, J.; Gomperts, R.; Stratmann, R. E.; Yazyev, O.; Austin, A. J.; Cammi, R.; Pomelli, C.; Ochterski, J. W.; Martin, R. L.; Morokuma, K.; Zakrzewski, V. G.; Voth, G. A.; Salvador, P.; Dannenberg, J. J.; Dapprich, S.; Daniels, A. D.; Farkas, Ö.; Foresman, J. B.; Ortiz, J. V.; Cioslowski, J.; Fox, D. J. Gaussian 09, Revision A.02; Gaussian: Wallingford CT, 2009.

16. Glendening, E. D.; Reed, A. E.; Carpenter, J. E., Weinhold, F. NBO Version 3.1; Theoretical Chemistry Institute, University of Wisconsin: Madison, WI, 1998.

17. Ditchfield, R. Mol. Phys. 1974, 27, 789-807.

18. Todd, A.; Keith, T. K. AIM All (Version 13.02.26); Gristmill Software: Overland Park KS, USA, 2012; (aim.tkgristmill.com). 